\title{
EKSTRAK DAUN Nicotiana tabacum MENURUNKAN BERAT LEMAK VISCERAL PADA TIKUS DIABETES MELLITUS TIPE DUA
}

\author{
Ratih Paramita Suprapto*® ${ }^{* \varpi}$, Andrew Jonathan ${ }^{* *}$, Shelby A Ernanda**, Budi Wicaksono*
}

\begin{abstract}
Abstrak
Diabetes mellitus merupakan masalah utama kesehatan di dunia dan prevalensinya selalu meningkat. Pada dosis yang tepat kandungan nikotin dari ekstrak etanol daun tembakau (Nicotiana tabacum) memiliki efek hipoglikemik sehingga berpeluang sebagai terapi alternatif untuk diabetes mellitus. Namun, efeknya pada jaringan adipose penderita diabetes mellitus belum banyak diketahui. Tujuan dari penelitian ini adalah untuk mengetahui pengaruh ekstrak etanol daun tembakau terhadap berat lemak visceral tikus model diabetes mellitus. Pada penelitian ini tikus galur Wistar dibagi menjadi 5 kelompok yaitu kontrol negatif (K-), kelompok tikus model diabetes mellitus $(\mathrm{K}+)$, dan tiga kelompok tikus diabetes melitus yang diberi ekstrak etanol daun tembakau 90 (P1), 180 (P2) dan 270 (P3) mg/kgBB/hari per oral selama 28 hari. Hasil penelitian menunjukkan bahwa terdapat penurunan bermakna berat lemak pada semua kelompok tikus DM yang diberi ekstrak daun tembakau dibandingkan dengan tikus DM tanpa terapi maupun tikus normal $(p<0,05)$. Kesimpulan penelitian adalah pemberian ekstrak etanol daun tembakau menurunkan berat lemak visceral pada tikus model DM. Penurunan berat lemak visceral kemungkinan disebabkan oleh kandungan nikotin dalam ekstrak yang dapat mengaktivasi lipolisis, menghambat lipogenesis, aktivasi thermogenesis, dan penurunan intake makan.
\end{abstract}

Kata kunci: berat lemak visceral, diabetes mellitus, daun tembakau (Nicotiana tabacum).

\section{ETHANOL EXTRACT OF Nicotiana tabacum REDUCES THE VISCERAL WEIGHT OF TYPE TWO DIABETIC RATS}

\begin{abstract}
Diabetes mellitusis the main health problem in the world and its prevalence is increasing dramatically. Tobacco leaf (Nicotiana tabacum) containing nicotine could be used as an alternative treatment for diabetes mellitus at the right dose. However, its effect on adipose tissue of diabetes mellitus model has not established well. This study aim is to observe the effect of ethanol extract of tobacco leaf to the visceral weight of diabetic rats. Rats were divided into five group normal rats $(\mathrm{K}-)$, diabetic rats $(\mathrm{K}+)$ and diabetic rats receiving ethanol extract of tobacco leaf at dose 90 (P1), 80 (P2), and 270 (P3) mg/kgBW/day orally for 28 days. Rats were sacrificed and visceral fat was weighed afterward. As the result, visceral fat of diabetic rats was less than the normal rats and diabetic rats treated with ethanol extract of tobacco leaf shown to reduce visceral weight significantly compared to normal rats $(p<0.05)$. Visceral weight decrement was due to nicotine effect that could induce lipolysis, inhibit lipogenesis, thermogenesis activation, and reduce food intake. Further research is needed to explore Nicotiana tabacum as an alternative treatment for diabetes mellitus.
\end{abstract}

Keywords: diabetes mellitus, tobacco leaf (Nicotiana tabacum), visceral weight.

* Laboratorium Fisiologi, FK UB
${ }^{*}$ Program Studi Pendidikan Dokter, FK UB

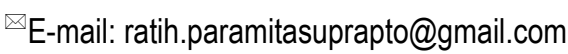




\section{Pendahuluan}

Diabetes mellitus (DM) merupakan masalah utama kesehatan di dunia. Terdapat 415 juta orang yang menderita DM di dunia dan diperkirakan pada tahun 2040 akan meningkat tajam menjadi 2.152 juta. Di Indonesia pada tahun 2015 terdapat 10 juta penderita DM. Dengan penderita terbanyak pada usia di bawah 60 tahun. ${ }^{1}$ Penderita DM di Indonesia diperkirakan akan terus meningkat menjadi 8,2 juta pada tahun 2020. ${ }^{2}$ DM adalah penyakit metabolik akibat tubuh gagal meregulasi kondisi hiperglikemia akibat gangguan sekresi insulin dan atau resistensi terhadap insulin. Karakteristik DM yang lain adalah hambatan lipogenesis dan lipolisis yang berlebihan akibat defisiensi atau resistensi terhadap insulin. ${ }^{3}$

Berbagai macam terapi telah ditemukan untuk mengontrol kadar gula darah pada pasien DM. Kontrol gula darah dengan baik akan mencegah kejadian komplikasi penyakit DM. Pemberian obat pengontrol gula darah sering kali harus diberikan seumur hidup akibat kegagalan tubuh menormalkan kondisi hipergliklemia. Namun, konsumsi obat diabetes dalam jangka waktu lama juga dapat berakibat adanya efek samping pada beberapa organ seperti saluran pencernaan, hati dan ginjal. 4,5 Oleh karena itu, diperlukan penemuan obat alternatif, di antaranya dari tanaman.

Pada penelitian terbaru, dengan dosis dan penggunaannya yang tepat, kandungan nikotin dan flavonoid dalam tanaman tembakau dapat digunakan sebagai terapi pencegahan komplikasi diabetes mellitus dengan cara menghambat perubahan karbohidrat menjadi glukosa dan meningkatkan sekresi insulin. 6,7 Pada penelitian ini dilihat pengaruh ekstrak etanol daun tembakau terhadap berat lemak tikus yang diinduksi DM tipe 2 .

\section{Bahan dan Metode}

Material dan Ekstraksi Tanaman

Daun tembakau (Nicotiana tabacum) didapatkan dari Bondowoso, Jawa Timur. Tembakau yang segar dipotong tipis-tipis dan digiling. Sebanyak $120 \mathrm{~g}$ daun tembakau dilarutkan dengan aquades. Setelah itu, dimaserasi dengan etanol $90 \%$ selama satu hari. Saring bahan baku yang telah dimaserasi menggunakan kertas saring Whatman. Ambil filtrat kemudian diuapkan (dipanaskan) di atas magnetic stirer dengan kecepatan agitator sedang hingga tercapai $3 / 4$ volume mula-mula. Ekstrak etanol hasil penguapan filtrat dicampur dengan aquades dan $n$-hexane didalam corong pemisah dengan perbandingan 2:1:2. Kocok ketiga campuran tersebut selama 10 menit hingga terbentuk dua lapisan tidak saling larut (immiscible) yaitu lapisan $n$-hexane dan lapisan campuran etanol-air. Lalu, ekstrak etanol diasamkan dengan asam sitrat 0,2 N sampai $\mathrm{pH}$ 3. Larutan dipisahkan dengan diuapkan dengan dengan rotary evaporator sehingga didapat ekstrak etanol kemudian ekstrak dikeringkan.

\section{Subjek Penelitian}

Subjek penelitian adalah model tikus Wistar (Rattus novergicus) jantan berusia 810 minggu. Tikus Wistar dipilih berdasarkan kriteria inklusi sebanyak 24 ekor, umur 2 bulan (150-200 gf). Kemudian dikondisikan di kandang pemeliharaan selama 2 minggu dengan diberikan diet chow standart pada kelompok kontrol negatif. Pada kelompok kontrol positif diberi diet tinggi lemak dan disuntik STZ. Jumlah konsumsi makanan harian maksimum sebanyak $40 \mathrm{~g} / \mathrm{tikus} / \mathrm{hari}$. Pemberian diet tinggi lemak dilakukan selama 16 hari. Kemudian tikus dipuasakan selama 16 jam lalu diinjeksi dengan STZ $22,5 \mathrm{mg} / \mathrm{kgBB}$ intraperitonial. Setelah 3 hari pasca induksi STZ dilakukan pemeriksaan gula darah (sebelumnya dipuasakan selama 
6 jam). Bila kadar gula darah mencapai $>140 \mathrm{mg} / \mathrm{dl}$ menggunakan glukometer, maka dikategorikan hiperglikemia ${ }^{8}$ dan selanjutnya tikus diberi perlakuan dengan ekstrak daun tembakau.

Pembagian kelompok pada tikus adalah sebagai berikut:

1. Kontrol negative (K-) $(n=5)$ : Tikus sehat tanpa diberikan perlakuan apapun.

2. Kontrol positif $(K+) \quad(n=5)$ : Tikus diinduksi menjadi DM tipe 2 tanpa pemberian ekstrak etanol tembakau.

3. Perlakuan $1(P 1)(n=5)$ : Tikus diinduksi menjadi DM tipe 2 dan diberikan pemberian ekstrak etanol tembakau 90 $\mathrm{mg} / \mathrm{kgBB} / \mathrm{hari}$.

4. Perlakuan $2(P 2)(n=5)$ : Tikus dinduksi menjadi DM tipe 2 dan diberikan pemberian ekstrak etanol tembakau180 $\mathrm{mg} / \mathrm{kgBB} / \mathrm{hari}$.

5. Perlakuan $3(P 3)(n=5)$ : Tikus dinduksi menjadi DM tipe 2 dan diberikan pemberian ekstrak etanol tembakau 270 $\mathrm{mg} / \mathrm{kgBB} / \mathrm{hari}$.

Setelah 28 hari perlakuan, tikus kemudian dibedah dan diambil jaringan adiposa di area peritoneum dan ditimbang menggunakan timbangan digital.

Analisis secara statistik menggunakan one way ANOVA pada $\alpha=0.05$. Penelitian dilakukan setelah mendapat surat persetujuan etik penelitian.

\section{Hasil}

Berat lemak visceral yang diperoleh dari area peritoneum tikus coba diperlihatkan pada Tabel 1 dan diagram batang pada Gambar 1. Hasil memperlihatkan adanya penurunan lemak visceral pada tikus DM, meskipun secara statistik tidak bermakna antara kontrol negatif dengan kontrol positif. Pemberian ekstrak etanol daun tembakau semakin menurunkan lemak visceral secara signifikan dibanding kontrol positif. Penurunan berat lemak visceral semakin besar seiring dengan peningkatan dosis. Penurunan yang bermakna dan paling besar adalah pada pemberian ekstrak sebesar 270 $\mathrm{mg} / \mathrm{kgBB}$ bila dibandingkan dengan tikus DM tanpa terapi.

Tabel 1. Berat lemak peritoneum tikus Wistar model DM tipe 2 yang diberi ekstrak daun tembakau

\begin{tabular}{llcc}
\hline No & Kelompok Perlakuan & \multicolumn{2}{c}{ Berat Lemak Visceral } \\
\cline { 2 - 4 } & & Rata - rata $(\mathrm{g})$ & \pm SD \\
\hline 1 & Kontrol negatif $(\mathrm{K}-)$ & $3,672^{\mathrm{a}}$ & 1,019 \\
\hline 2 & Kontrol positif $(\mathrm{K}+)$ & $2,562^{\mathrm{a}}$ & 1,571 \\
\hline 3 & Ekstrak daun tembakau $90 \mathrm{mg} / \mathrm{kgBB}(\mathrm{P} 1)$ & $1,5766^{\mathrm{b}}$ & 0,606 \\
\hline 4 & Ekstrak daun tembakau180 $\mathrm{mg} / \mathrm{kgBB}(\mathrm{P} 2)$ & $1,404 \mathrm{~b}$ & 0,537 \\
\hline 5 & Ekstrak daun tembakau270 $\mathrm{mg} / \mathrm{kgBB}(\mathrm{P} 3)$ & $0,218^{\mathrm{ab}}$ & 0,245
\end{tabular}

Keterangan: nilai $p=0,001$ 


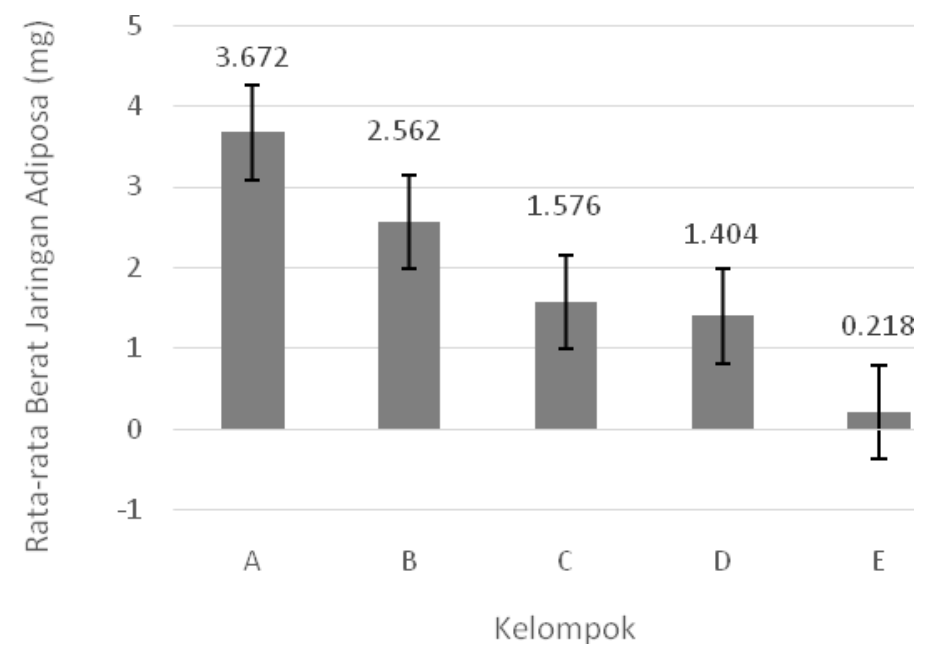

Gambar 1. Efek ekstrak etanol daun tembakau terhadap lemak visceral tikus model diabetes mellitus (DM). Keterangan: A. Kontrol negatif (K-), B. Kontrol positif (DM) $(K+)$, C. DM + ekstrak daun tembakau $90 \mathrm{mg} / \mathrm{kgBB} / \mathrm{hari}$ (P1), D. DM + ekstrak daun tembakau180mg/kgBB/hari (P2), E : DM + ekstrak daun tembakau $270 \mathrm{mg} / \mathrm{kgBB} / \mathrm{hari}$ (P3).

\section{Pembahasan}

Tikus yang diinduksi diabetes mellitus menunjukkan penurunan berat lemak visceral meskipun tidak signifikan. Hal ini telah sesuai dengan patofisiologi diabetes mellitus yaitu terjadi lipolisis yang berlebihan. Lipolisis pada diabetes mellitus adalah akibat defisiensi insulin sehingga tidak adanya hambatan terhadap enzim hormone sensitive lipase (HSL) di jaringan adiposa dan hati. Aktivasi HSL selanjutnya akan mengaktifkan lipolisis yang mengubah trigliserida menjadi asam lemak dan gliserol. ${ }^{8}$

Selain itu, defisiensi insulin juga berakibat pada penurunan aktivitas lipoprotein lipase $(\mathrm{LPL}){ }^{9} \quad$ Enzim $\mathrm{LPL}$ ditemukan terutama di lapisan pembuluh darah kapiler di otot skeletal dan jaringan adiposa. LPL berperan memecah trigliserida yang berada di liporotein (trigliserida tersebut dibawa dari organ lain dan berada di peredaran darah). LPL menguraikan trigliserida menjadi asam lemak dan gliserol sehingga dapat masuk ke dalam jaringan otot skeletal atau adiposa kemudian digunakan sebagai bahan bakar atau disimpan. ${ }^{10}$

Ekstrak daun tembakau mengandung bahan utama yaitu nikotin. ${ }^{11}$ Dalam hal nikotin yang terhirup, akan mencapai otak dan mengaktivasi reseptor asetilkolin nikotinik (nAChR) yang tersebar pada sistem saraf pusat dan perifer serta jaringan perifer lainya. ${ }^{12}$ Efek pada otak adalah meningkatkan neurotransmiter terutama dopamin yang mengakibatkan efek adiksi terhadap nikotin. ${ }^{13}$ Efek pada jaringan perifer dan sistem saraf perifer adalah kontraksi otot skeletal. Namun pada medulla adrenal adalah meningkatkan katekolamin, efek ini merupakan efek dominan yang terjadi pada manusia akibat nikotin. ${ }^{14}$

Penelitian ini menunjukkan bahwa pemberian ekstrak daun tembakau (Nicotiana tabacum) semakin menurunkan berat lemak visceral, semakin besar dosis ekstrak yang diberikan maka semakin besar pula penurunan berat lemak viseral. Penelitian oleh Anderson dan Arner (2001) telah menunjukkan bahwa nikotin menginduksi lipolisis sebagian dengan cara menginduksi pelepasan katekolamin. 
Katekolamin akan mengaktivasi reseptor beta adrenergik di sel adiposa kemudian menginduksi jaras untuk lipolisis. ${ }^{15}$

Peningkatan lipolisis akan meningkatkan konsentrasi asam lemak. Peningkatan turn over asam lemak berhubungan dengan overproduksi VLDL, trigliserida, LDLC, dan HDLC yang lebih rendah. Pemberian tembakau pada manusia meningkatkan kadar trigliserida dan VLDL serta menurunkan kadar HDLc. Efek ini diakibatkan oleh nikotin, sebagaimana dikonfirmasi oleh peningkatan kadar nikotin. ${ }^{16}$

Selain itu, nikotin juga diduga secara langsung mengaktivasi reseptor kolinergik nikotinik di jaringan adiposa. Pada akhirnya, terjadi peningkatan gliserol dan asam lemak bebas di darah akibat pemberian nikotin secara sistemik. Meskipun demikian, keberadaan reseptor kolinergik nikotinik pada sel adiposit masih memerlukan penelitian lebih lanjut. ${ }^{17}$

Penelitian lainnya yang membuktikan mekanisme penyebab penurunan berat lemak yaitu penurunan aktivitas LPL pada tikus yang diberi nikotin jangka lama tetapi tanpa disertai penurunan jumlah protein atau mRNA LPL. ${ }^{18}$ Nikotin juga diketahui menghambat lipogenesis dengan mekanisme perantara yaitu peningkatan aktivitas AMP-activated Protein Kinase (AMPK) ${ }^{19}$.

Selain aktivasi lipolisis, inhibisi lipogenesis dan penurunan penyimpanan lemak oleh sel, penurunan berat lemak visceral pada pemberian ekstrak tembakau juga dapat disebabkan oleh peningkatan aktivitas thermogenesis pada jaringan adiposa coklat melalui aktivasi sistem saraf simpatis dan peningkatan uncoupling protein 1.20-22 Nikotin dapat meningkatkan pengeluaran katekolamin dan asetilkolin oleh sel adrenal. ${ }^{23}$ Epinefrin dan norepinefrin selanjutnya mengaktivasi thermogenesis di jaringan lemak coklat. ${ }^{24}$
Penurunan berat lemak juga dapat disebabkan oleh penurunan intake makan pada tikus yang diberikan esktrak etanol tembakau. ${ }^{25}$ Pemberian nikotin pada tikus diketahui menurunkan nafsu makan melalui aktivasi reseptor melanocortin-4 (MC4R) yang terekspresi pada neuron hipothalamus pro-opiomelanocortin (POMC) yang menimbulkan rasa kenyang. ${ }^{26,27}$ Meskipun demikian, aktivasi neuropeptida $Y$ (NPY) pada hipothalamus dan orexin juga diamati setelah pemberian nikotin selama 7 minggu. NPY dan orexin dapat meningkatkan nafsu makan. ${ }^{27}$

Nikotin ikut terhirup pada saat seseorang merokok atau terpapar asap rokok. Nikotin yang menyebabkan penurunan berat badan juga sejalan dengan hasil beragam studi observasi bahwa berhenti merokok dapat menimbulkan kegemukan. ${ }^{28}$ Selain itu, berhenti merokok menormalkan nafsu makan, thermogenesis, dan mobilisasi lipid melalui aktivitas AMPK. ${ }^{22}$

Pada penelitian yang dilakukan oleh Hosseini et al. (2011) bahwa pemberian nikotin secara intraperiotenial dengan dosis kecil $(0,5 ; 1 ; 1,5 \mathrm{mg} / \mathrm{kgBB})$ menunjukkan efek peningkatan sekresi insulin. ${ }^{8}$ Selain itu, penelitian oleh Kazeem et al. (2014) yang memperlihatkan pemberian efek ekstrak etanol daun tembakau diduga dapat menurunkan kadar glukosa darah melalui hambatan terhadap a-amylase dan aglucosidase. Hambatan terhadap kedua hormon tersebut menyebabkan karbohidrat tidak diubah menjadi monosakarida sehingga mencegah hiperglikemi. ${ }^{7}$ Kemungkinan dosis yang dipakai dalam penelitian ini terlampau besar sehingga efek nikotin untuk sekresi insulin dan hambatan terhadap enzim pemecah karbohidrat tidak terjadi. Untuk itu, diperlukan penelitian lebih lanjut untuk mengetahui dosis nikotin yang tepat sebagai terapi alternatif diabetes mellitus (DM). 


\section{Kesimpulan}

Ekstrak etanol daun tembakau
(Nicotana tabacum) menyebabkan penurunan berat lemak visceral pada tikus model diabetes mellitus, diduga melalui beberapa mekanisme yaitu peningkatan lipolisis, penurunan lipogenesis, peningkatan aktivasi thermogenesis dan penurunan nafsu makan. Diperlukan penelitian lebih lanjut dan dengan dosis yang lebih tepat untuk membuktikan bahwa ekstrak daun tembakau dapat bermanfaat sebagai terapi alternatif diabetes mellitus.

\section{Daftar Pustaka}

1. International Diabetes Federation. (Online). 2015. http://www.idf.org. Diakses 20 Maret 2017.

2. Tendra, H. Segala Sesuatu yang Harus Anda Ketahui Tentang Diabetes. Jakarta: PT Gramedia Pustaka Utama. 2008.

3. Choi SM, Tucker DF, Gross DN, Easton RM, DiPilato LM, Dean AS, Monks $B R$, and Birnbaum MJ. Insulin Regulates Adipocyte Lipolysis via An AktIndependent Signaling Pathway. Mol Cell Biol. 2010; 30(21): 5009-5020.

4. Andayani TM, Ibrahim MIM, dan Asdie $\mathrm{AH}$. The Effect of Combination Therapy of Sulfonylurea, Metformin, and Acarbose in Type 2 Diabetes Mellitus Patients. Majalah Farmasi Indonesia. 2009; 20(4):224 - 230.

5. Diabetes Medication Side Effects. (Online). 2017. http://www.diabetes.co.uk. Diakses 13 Mei 2017.

6. Kazeem MI, Ogungbe SM, Saibu GM, Aboyade OM. In vitro Study on the Hypoglicemic Potential of Nicotiana tabacum Leaf Extracts. Bangladesh J Pharmacol. 2014; 9:140-145.

7. Hosseini E. The Effect of Nicotine on the Serum Level of Insulin in Adult Male
Wistar Rats. Journal of Cell and Animal Biology. 2011; 5(10):215-218.

8. Donnelly $\mathrm{KL}$, Smith $\mathrm{Cl}$, Schwarzenberg SJ, et al. Sources of Fatty Acids Stored in Liver and Secreted Via Lipoproteins in Patients with Nonalcoholic Fatty Liver Disease. J Clin Invest. 2005; 115:13431351.

9. Guyton and Hall. Textbook of Medical Physiology. $12^{\text {th }}$ Edition.Singapore: Elsevier. 2014. P 1027.

10. Taskinen MR. Lipoprotein Lipase in Diabetes. Diabetes Metab Rev. 1987; 3(2):551-70.

11. Doolittle DJ, Winegar R, Lee CK, Caldwell WS, Hayes AW, de Bethizy JD. The Genotoxic Potential of Nicotine and Its Major Metabolites. Mutat Res. 1995; 344:95-102.

12. Run-Hua Liu, Masanari M., and Matsukura S. The Expression and Functional Role of Nicotinic Acetylcholine Receptors in Rat Adipocytes. $J$ Pharmacol Exp Ther. 2004; 310:52-58.

13. Dani JA, De Biasi M. Cellular Mechanisms of Nicotine Addiction. Pharmacol Biochem Behav. 2001; 70:439-446.

14. Tweed JO, Hsia SH, Lutfy $\mathrm{K}$, and Friedman TC.The Endocrine Effects of Nicotine and Cigarette Smoke. Trends Endocrinol Metab. 2012; 23(7): 334-342.

15. Genetic Home Reference. LPL Gene. (Online). 2017. http://ghr.nlm.nih.gov. Diakses 22 Maret 2017.

16. Thorat JS, Joshi AG, Wingkar KC, and Sontakke AV. Effect of Smokeless Tobacco Consumption on Lipid Profile. RJPBCS. 2014; 5(6):1260-1266.

17. Andersson K, Arner P. CholinoceptorMediated Effects on Glycerol Output from Human Adipose Tissue using In Situ Microdialysis. $\mathrm{Br} J$ Pharmac. 1995; 115:1155-1162.

18. Andersson $\mathrm{K}$ and Arner P. Systemic Nicotine Stimulates Human Adipose 
19. Tissue Lipolysis Through Local Cholinergic and Catecholaminergic Receptors. Int J Obes 2001; 25(8):12251232.

20. Sztalryd C, Hamilton J, Horwitz BA, Johnson $\mathrm{P}$, Kraemer FB. Alterations of Lipolysis and Lipoprotein Lipase in Chronically Nicotine-Treated Rats. Am J Physiol. 1996; 270(2 Pt 1):E215-23.

21. An Z, Wang $H$, Song $P$, Zhang $M$, Geng $X, Z$ ou MH. Nicotine-Induced Activation of AMP-Activated Protein Kinase Inhibits Fatty Acid Synthase in 3T3L1 Adipocytes: a Role for Oxidant Stress. J Biol Chem. 2007; 282(37):26793-801.

22. Martínez de Morentin PB, Whittle AJ, et al. Nicotine Induces Negative Energy Balance Through Hypothalamic AMPActivated Protein Kinase. Diabetes. 2012; 61:807-817.

23. Yoshida T, Sakane N, Umekawa T, et al. Nicotine Induces Uncoupling Protein 1 in White Adipose Tissue of Obese Mice. Int J Obes Relat Metab Disord. 1999; 23:570 $-575$.

24. Arai K, Kim K, Kaneko K, et al. Nicotine Infusion Alters Leptin and Uncoupling Protein 1 mRNA Expression in Adipose

30.1638.
Tissues of Rats. Am J Physiol Endocrinol Metab. 2001; 280:E867-E876.

25. Mizobe F, Livett BG. Nicotine Stimulates Secretion of Both Catecholamines and Acetylcholinesterase from Cultured Adrenal Chromaffin Cells. J Neurosci. 1983; 3(4):871-6.

26. Harms $M$ and Seale P. Brown and Beige Fat: Development, Function and Therapeutic Potential.Nature Medicine2013; 19: 1253-1262.

27. Mineur YS, Abizaid A, Rao Y, Salas R, DiLeone RJ, Gündisch D, Diano S, De Biasi M, Horvath TL, Gao XB, Picciotto MR. Nicotine Decreases Food Intake Through Activation of POMC Neurons. Science. 2011; 332:1330-1332.

28. Huang $\mathrm{H}, \mathrm{Xu} \mathrm{Y}$, van den Pol AN.Nicotine Excites Hypothalamic Arcuate Anorexigenic Propiomelanocortin Neurons and Orexigenic Neuropeptide $Y$ Neurons: Similarities and Differences. $J$ Neurophysiol. 2011; 106:1191-1202.

29. Lisa AP and Johnsen S. Smoking Cessation, Obesity and Weight Concerns in Back Women: A Call Culturally Competent Interventions. Original Communication. Journal of National Medical Association. 2005; 97(12):1630- 